\title{
EFFECT OF PREHEATING ON MECHANICAL PROPERTIES IN INDUCTION SINTERING OF METAL-POWDER MATERIAL Fe AND $w(\mathrm{Cu})=3 \%$
}

\author{
VPLIV PREDGREVANJA NA MEHANSKE LASTNOSTI \\ INDUKCIJSKO SINTRANEGA MATERIALA, IZDELANEGA IZ \\ KOVINSKEGA PRAHU Fe IN $w(\mathrm{Cu})=3 \%$
}

\author{
Göksan Akpınar', Enver Atik ${ }^{2}$ \\ ${ }^{1}$ Celal Bayar University, Hasan Ferdi Turgutlu Faculty of Technology, Manufacturing Engineering Department, 45400 Turgutlu/Manisa, Turkey \\ ${ }^{2}$ Celal Bayar University, Engineering Faculty, Mechanical Engineering Department, 45040 Manisa, Turkey \\ goksanakpinar105@hotmail.com \\ Prejem rokopisa - received: 2014-08-29; sprejem za objavo - accepted for publication: 2014-09-24
}

doi:10.17222/mit.2014.215

\begin{abstract}
In this study, the sintering process of iron-based powder-metal parts through induction and in a classic resistance furnace was analyzed experimentally and theoretically. Within the scope of the study, the Högenas ASC 100.29 iron powder containing mass fractions $w(\mathrm{Cu})=3 \%, 0.5 \%$ graphite and, as a lubricant, $0.8 \%$ Kenolub was used. The effects of preheating, sintering time, conveyor-belt speed and gradual cooling on the sintering with induction, and the effects of the sintering parameters on the mechanical properties of the samples were analyzed experimentally and numerically. In the study, preheating with the induction adjustable at a low or mid $(2.5-5 \mathrm{kHz})$ frequency was tested. By means of applying preheating and sintering in an atmosphere of argon gas, the thermal shock on the samples was blocked and superior physical and mechanical properties were achieved.

Keywords: powder metallurgy, sintering with induction, preheating, classical furnace, finite-element method, resistivity
\end{abstract}

V tej študiji smo eksperimentalno in teoretično analizirali proces sintranja kovinskih delov na osnovi železovega prahu. Uporabljen je bil komercialni Högenasov železov prah ASC 100,29, ki je vseboval masne deleže $w(\mathrm{Cu})=3 \%, 0,5 \%$ grafita in $0,8 \%$ maziva Kenolub. Vpliv predgrevanja, časa sintranja, hitrosti pomikanja traku in postopno ohlajanje pri indukcijskem sintranju na mehanske lastnosti vzorcev so bili analizirani eksperimentalno in numerično. V študiji je bilo preizkušeno predgretje z regulirano indukcijo pri nizki in srednji frekvenci $(2,5-5 \mathrm{kHz})$. S predgrevanjem in postopkom sintranja $\mathrm{v}$ atmosferi argona je bil preprečen toplotni šok pri vzorcih in dobljene so bile boljše fizikalne in mehanske lastnosti.

Ključne besede: metalurgija prahov, indukcijsko sintranje, predgrevanje, klasična peč, metoda končnih elementov, upornost

\section{INTRODUCTION}

The PM manufacturing method is the process of producing metal powders and transforming the produced powders into desired parts. This method consists of a series of stages including powder production, mixing of the powders produced, powder pressing, sintering and optional processes (infiltration, oil impregnation, dewaxing, etc.). ${ }^{1}$

Sintering is a process of heating which results in a considerable resistance increase due to the bonding of particles and in improved characteristics. Sintering enables the particles to contact each other so as to bond at high temperatures. This bonding may occur due to the atom movements (the diffusion) in the solid state below the melting temperature. However, in many cases, it is accompanied by the formation of the liquid phase. ${ }^{2}$ Prior to sintering, the polymers used as binders or lubricants should be removed. The polymer-combustion process occurs during the heating of the polymer up to the decomposition temperatures at which it loses stability and decomposes into its components. The heat initially melts the polymer and afterwards enables the emergence of small molecules that are separated, due to evaporation, from the crude parts. The atmosphere in the combustion process is important since the active gases result in either an easy separation of the polymer or a reaction with the powders. A weight decrease shows that during the heating of the mass of the pressed stainless-steel powder at a $10{ }^{\circ} \mathrm{C} / \mathrm{min}$ rate, the lubricating polymers do not gradually separate from the mass. If a proper time-dependent heat input is not provided to the powder materials during the sintering process, the polymer is likely to be still included in the mass of the material. Thus, the time-dependent heat input should be set very well during the sintering. Most of the lubricants used in powder metallurgy are melted below $1500{ }^{\circ} \mathrm{C}$, but they are not vaporized up to a temperature of $300-500{ }^{\circ} \mathrm{C}$. To prevent damage to the raw part, the heating speed at the stage with a weight loss should be slow. The combustion process is shown in different atmospheres at a fixed heating rate. When carrying out a complete combustion of argon and hydrogen, a weight increase after the combustion occurs since air and nitrogen enter into a reaction. In the applications where crude density is very high, the 
heating rate should be slow since the polymer/lubricator evaporation is difficult because of open porosity. ${ }^{2}$

Compared to the conventional heating systems, the heating with induction has advantages such as a considerably shorter processing time, no environmental heat distribution, being clean and highly productive, being controllable and repeatable, being subjected to a precise temperature control, no air pollution due to the gases used in the furnaces and during the combustion, no by-products in the heating area, minimum ventilation and smoke output thanks to the absence of the combustion by-products and radiation and being a secure system not causing the events such as explosions. As a result of these benefits, the use of this heating system in the industry has increased recently. Induction is used for many purposes in the industry. It is widely used in the processes such as hard soldering, surface hardening, welding, forging, annealing, heat treatment and smelting. ${ }^{3,4}$

In recent years, powder metallurgy has led to major innovations in different areas in order to meet the demand for more mechanical features and competitive production costs for steel components. Recently, researches have focused on the materials achieving a high-performance with low costs. For this purpose, for particular powder compositions, new processes are continually developed for the pre-sintering, sintering and after-sintering stages. High-quality PM components are a result of these researches involving the induction-sintering process. Since the inner structures of powder-metal materials are porous, their electrical features are quite different compared to the bulk material. The extent of the porosity of the internal structure of a powder-metal material also strongly affects the mechanical properties by lowering the density and the Young's modulus of the material. In this study, we analyze how the changes in the parameters of the sintering with induction affect the interior structures of powder-metal materials; we also determine the internal structures and stress conditions under the ideal sintering conditions by analyzing the behaviors of the micro-stresses that occur within the internal structure of a material as a result of the loading conditions. In this context, it is considered that this study will shed light on the parameters of induction sintering of powder-metal particles in the industry and their usage conditions.

\section{MATERIALS AND METHODS}

In this study, the mechanical and micro-structural features of iron-based powder-metal samples sintered with induction and in a furnace at (0.2, 0.3 and 0.5) $\mathrm{mm} / \mathrm{s}$ conveyor speeds were analyzed. In addition, the effect of the preheating process at a frequency $2.5 \mathrm{kHz}$ during the sintering with induction on the microstructures and mechanical features of the PM samples was investigated. The samples obtained from the Högenas ASC 100.29 iron powder, whose chemical, physical and sieve features are given in Table $\mathbf{1}$, were subjected to the sintering process with induction and to the sintering in a furnace at different conveyor speeds. The samples were processed by preheating with induction at a medium and low frequency $(2.5 \mathrm{kHz})$ and by sintering at a medium frequency $(45 \mathrm{kHz})$. The test was conducted as a loca-

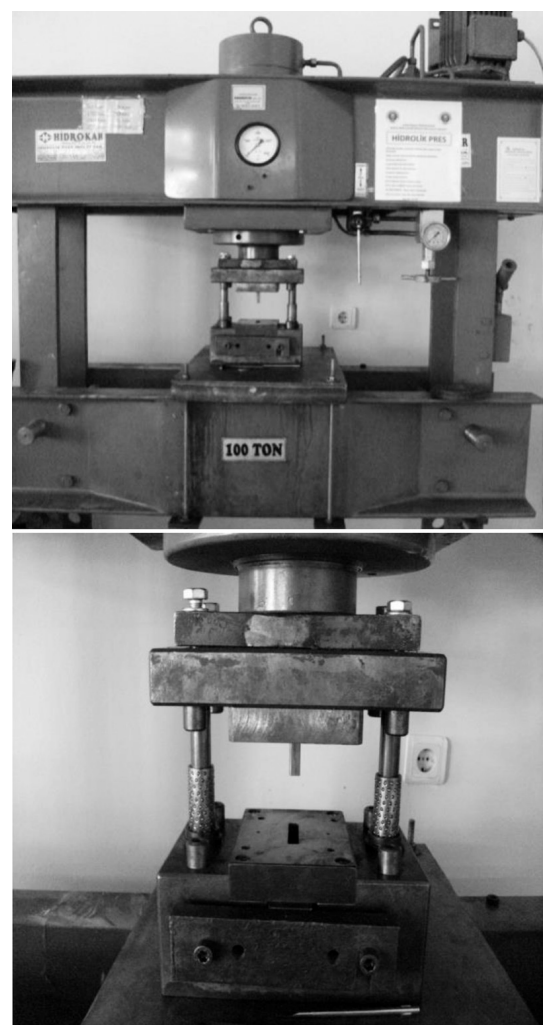

Figure 1: Images of the hydraulic press and the mold Slika 1: Fotografija hidravlične stiskalnice in modela

Table 1: PM-sample codes and applied procedures

Tabela 1: Oznake vzorcev in uporabljeni postopki

\begin{tabular}{|c|c|c|c|c|c|c|c|}
\hline Sample No. & Sample code & $\begin{array}{c}\text { Sintering } \\
\text { process }\end{array}$ & $\begin{array}{c}\text { Protective } \\
\text { atmosphere }\end{array}$ & $\begin{array}{c}\text { Conveyor-belt } \\
\text { speed (mm/s) }\end{array}$ & $\begin{array}{c}\text { Preheating } \\
\text { duration }(\mathrm{min})\end{array}$ & $\begin{array}{c}\text { Sintering time } \\
(\mathrm{min})\end{array}$ & $\begin{array}{c}\text { Density } \\
\left(\mathrm{g} / \mathrm{cm}^{3}\right)\end{array}$ \\
\hline 1 & K 0.2 & Induction & Argon & 0.2 & - & 17.08 & 7.457 \\
\hline 2 & K 0.3 & Induction & Argon & 0.3 & - & 11.38 & 7.197 \\
\hline 3 & K 0.5 & Induction & Argon & 0.5 & - & 6.83 & 7.135 \\
\hline 4 & Ö 0.3 & Induction & Argon & 0.3 & 11.27 & 11.38 & 7.485 \\
\hline 5 & Ö 0.5 & Induction & Argon & 0.5 & 6.76 & 6.83 & 7.318 \\
\hline 6 & F 1 & Furnace & Argon & - & 15 & 45 & 7.211 \\
\hline 7 & F 2 & Furnace & None & - & 15 & 45 & 7.184 \\
\hline
\end{tabular}




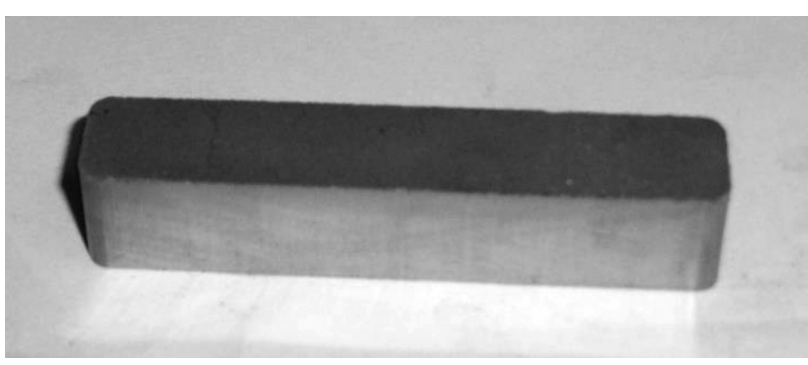

Figure 2: Cold-pressed sample of $10 \mathrm{~mm} \times 10 \mathrm{~mm} \times 55 \mathrm{~mm}$ in size Slika 2: Hladno stiskan vzorec dimenzij $10 \mathrm{~mm} \times 10 \mathrm{~mm} \times 55 \mathrm{~mm}$

tion- and speed-controlled procedure through a controlled conveyor using a programmable logic controller (plc).

In the beginning of the experimental study, the powders were weighed as 37.37 grams on a Sartorius BL 210S sensitive balance, filled into a mold cavity of 10 $\mathrm{mm} \times 10 \mathrm{~mm} \times 55 \mathrm{~mm}$ in size, and cold pressed in the mold at a pressure $600 \mathrm{MPa}$ via a Hidrokar hydraulic press for $10 \mathrm{~s}$. Graphite powder was used as the mold lubricant. The samples were then sintered with induction at three different conveyor speeds of $(0.2,0.3$ and 0.5$)$ $\mathrm{mm} / \mathrm{s}$. Also, in order to observe the effect of preheating with induction, some samples were treated with the preheating process. The concentrations of the PM samples were measured according to Archimedes' principle. The images of the press, the mold and the obtained sample are given in Figure 1. An image of the cold-pressed sample is given in Figure 2.

Table 1 gives the code names and test conditions for the samples sintered at different parameters, and Table 2 gives the Högenas ASC 100.29 iron powder, its chemical and physical properties as well as the sieve-analysis results. ${ }^{5}$

In order to prevent the harmful effects of the ambient atmosphere during the sintering of the PM samples with induction, the samples were passed through a heat-resistant quartz-glass tube and pure argon gas was sent to the environment. By means of the holes drilled into the quartz-glass tube, the evaporation of the lubricants and a direct measurement with the laser heat readers were ensured. In Figure 3, the quartz-glass tube, the heat readers and the procedure for removing the lubricant at $600{ }^{\circ} \mathrm{C}$ are shown.

The samples obtained from the iron-based ASC 100.29 powder were subjected to the sintering process

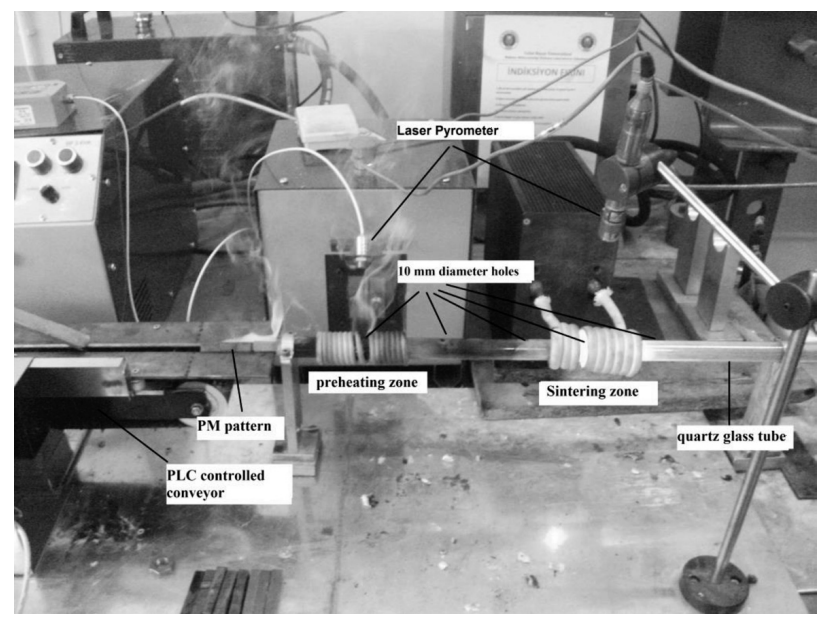

Figure 3: Induction test device

Slika 3: Indukcijska preizkusna naprava

with induction at the conveyor speeds of $(0.2,0.3$ and $0.5) \mathrm{mm} / \mathrm{s}$ and constantly in the furnace. Eight units were produced from each sample and they were used for the necessary mechanical, physical and microstructural analyses. The samples sintered with induction at different conveyor speeds (at different times) and in the furnace were subjected to metallographic and mechanical tests. The preheating temperature was defined as $600{ }^{\circ} \mathrm{C}$ and the sintering temperature as $1120^{\circ} \mathrm{C}$. For the sintering of the PM samples at $1120^{\circ} \mathrm{C}$, we used an induction device with a coil with a diameter of $8 \mathrm{~mm}$, a tunnel with a length of $95 \mathrm{~mm}$, a frequency of $45 \mathrm{kHz}$ with 9 wrappings, a power of $12 \mathrm{~kW}$ and a current intensity of $17.5 \mathrm{~A}$.

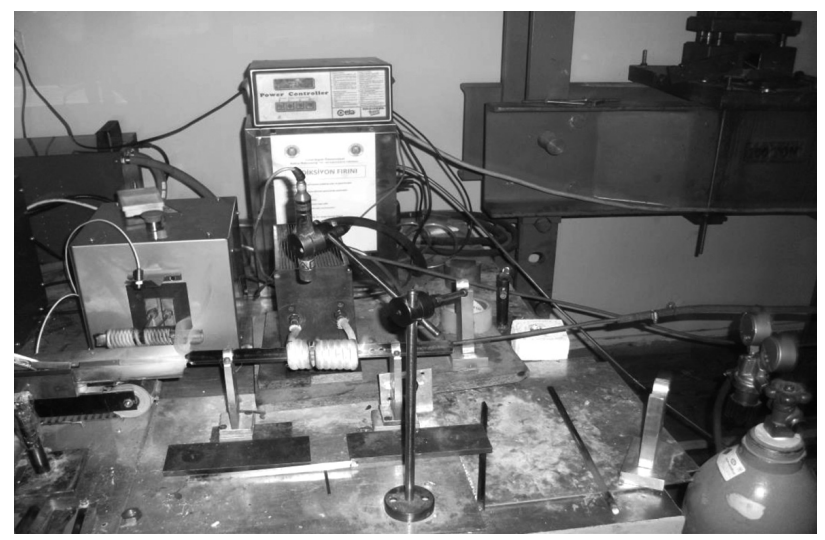

Figure 4: 45-kHz-frequency induction device

Slika 4: Indukcijska naprava s frekvenco $45 \mathrm{kHz}$

Table 2: Högenas ASC 100.29 iron powder, its chemical and physical properties and sieve analysis ${ }^{5}$

Tabela 2: Högenas ASC 100,29 Fe-prah: kemijske in fizikalne lastnosti ter sejalne analize ${ }^{5}$

\begin{tabular}{|c|c|c|c|c|c|}
\hline \multicolumn{2}{|c|}{ Chemical properties $\%$} & \multicolumn{2}{|c|}{ Physical properties } & \multicolumn{2}{|c|}{ Sieve analysis $\%$} \\
\hline $\mathrm{C}$ & 0.01 & Apparent density & $2.42 \mathrm{~g} / \mathrm{cm}^{3}$ & $<45 \mu \mathrm{m}$ & 23 \\
\hline $\mathrm{O}$ & 0.07 & Flow (Hall) & $31 \mathrm{~s} / 50 \mathrm{~g}$ & $45-150 \mu \mathrm{m}$ & 69 \\
\hline $\mathrm{Cu}$ & 3.0 & Compression pressure & 5.5 kbar (40 tsi) & $150-180 \mu \mathrm{m}$ & 8 \\
\hline Lubricant & 0.8 & & & $>180 \mu \mathrm{m}$ & 0 \\
\hline Iron & Balancing element & & & & \\
\hline
\end{tabular}


In Figure 4, an image of the induction device for the $1120{ }^{\circ} \mathrm{C}$ sintering section is given. When sintering the PM samples with induction and without preheating, it was observed that the lubricators separated fast on the samples and combusted because of the rapid heating. This adversely affected the mechanical and physical properties of the samples. The processing depth of the sintering area was detected through a numerical analysis. All the tests involving the sintering of the PM samples with induction were conducted in a protective atmosphere of argon gas.

\section{RESULTS}

\subsection{Three-point-bending test results for the powder- metal samples}

Three-point-bending tests of the powder-metal samples subjected to different sintering processes were conducted on the Shimadzu equipment. A three-point-bending device is shown in Figure 5. The average values were obtained by conducting four separate tests for each sample.

In the three-point-bending test, the dimensions of each sample were entered into the computer before the testing. The zeroing and calibration procedures were conducted at the start of each test. After placing the

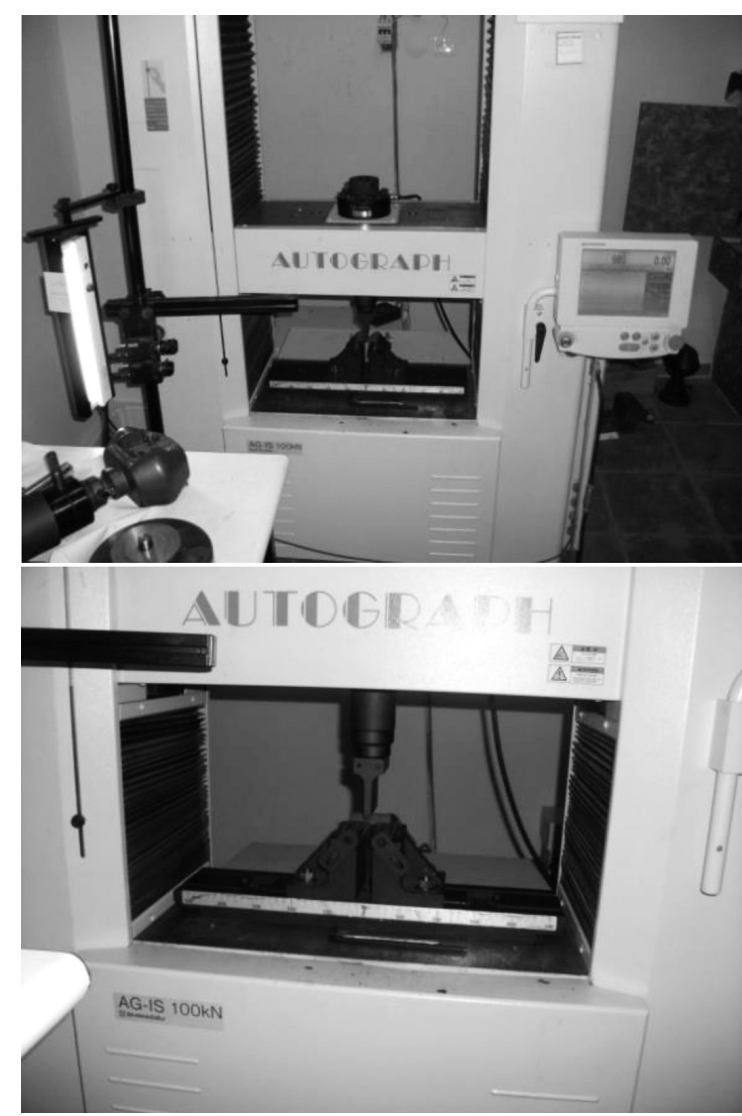

Figure 5: Three-point-bending test device

Slika 5: Tritočkovna upogibna naprava

\section{Stress-Strain (MPa-mm)}

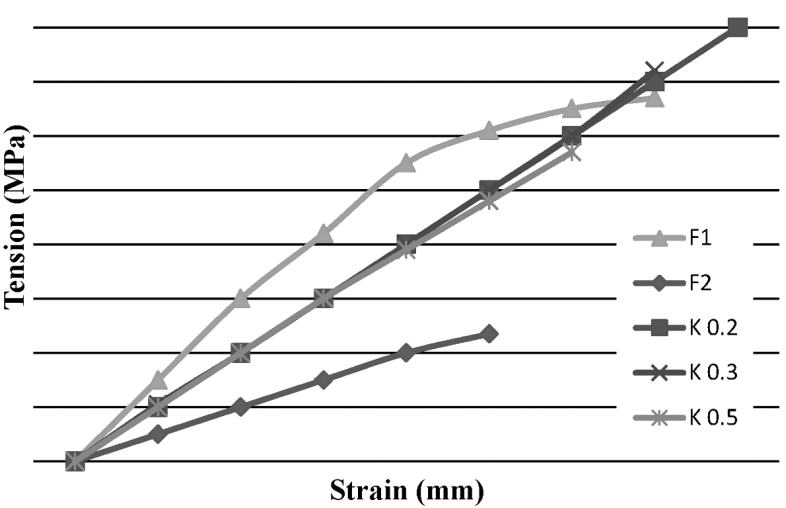

Figure 6: Three-point-bending test graphs of the samples sintered with induction without preheating in the furnace

Slika 6: Rezultati tritočkovnega upogibnega preizkusa indukcijsko sintranih vzorcev brez predgrevanja v peči

samples at a support distance $44 \mathrm{~mm}$, the pressure was applied at a bending speed $10 \mathrm{~mm} / \mathrm{min}$ and under a load $12 \mathrm{kN}$ until they were broken. The stress-strain (MPa mm) curves obtained from the average values of the threepoint-bending test of the samples are given in Figures 6 and 7.

In order to view the results of the three-point-bending test of the samples sintered with induction and in the furnace, they are shown in a single graph. The preheating duration for the samples processed with the preheating with induction at $600{ }^{\circ} \mathrm{C}$ is $11.38 \mathrm{~min}$ for the sample at the conveyor speed of $0.3 \mathrm{~mm} / \mathrm{s}$ and $6.83 \mathrm{~min}$ for the sample at the conveyor speed $0.5 \mathrm{~mm} / \mathrm{s}$.

\subsection{Hardness-test results}

The surface-hardness values for the PM samples were measured using the Brinell-hardness testing method. After the grinding of each sample, the load was applied using a diameter ball $2.5 \mathrm{~mm}$ end for $10 \mathrm{~s}$. By conduct-

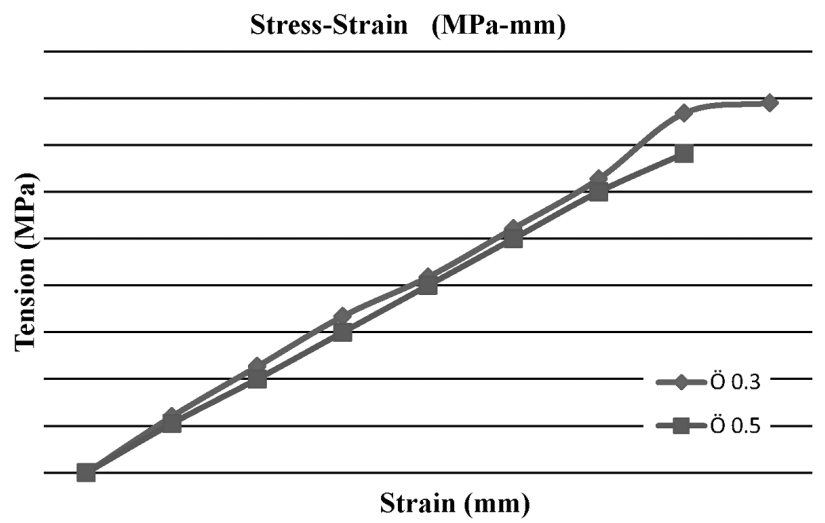

Figure 7: Three-point-bending test graphs of the samples sintered with induction and with preheating

Slika 7: Rezultati tritočkovnega upogibnega preizkusa indukcijsko sintranih vzorcev s predgrevanjem 


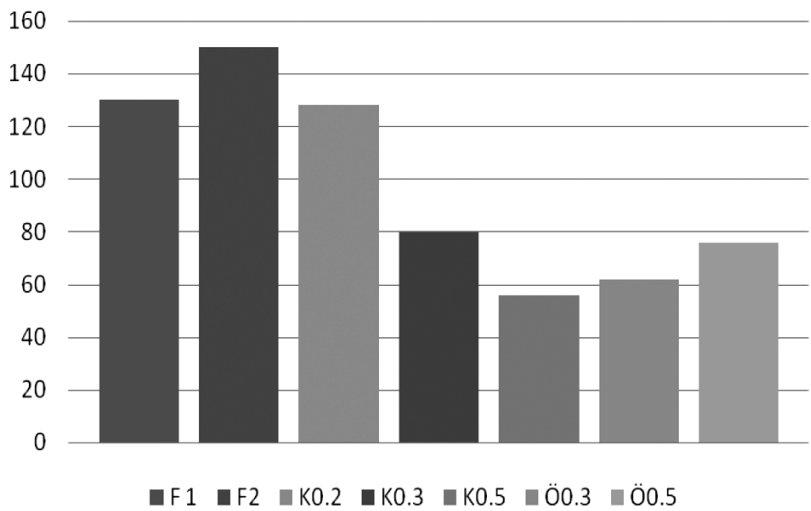

Figure 8: Brinell hardness of individual samples Slika 8: Trdota po Brinellu posameznih vzorcev

ing four hardness tests on the samples, the average values were obtained. The test results are given in Figure 8.

\subsection{Electrical analyses}

Due to the porous internal structure of the powdermetal samples, their resistivity is quite different compared to the bulk samples. In order to view the changes in the resistance of the powder-metal materials due to the temperature, a Hioki 3541 resistance-measuring device was used. After obtaining the real resistance-heat graphs for the iron-based powder-metal samples of $10 \mathrm{~mm} \times 10$ $\mathrm{mm} \times 55 \mathrm{~mm}$ in size and calculating the real resistivity values, these results were used in the numerical models. In this manner, we attempted to obtain the optimum sintering parameters. The resistivity of the PM samples greatly affects the sintering parameters and the heat generation in the material and processing depth. In Figure 9, the Hioki 3541 resistance-measuring device can be seen.

A Högenas ASC 100.29 iron-powder resistance-temperature graph and the average values are given in Figure 10 and Table 3.

The resistivity of the bulk metals, unlike that of the powder-metal materials, increases in direct proportion to

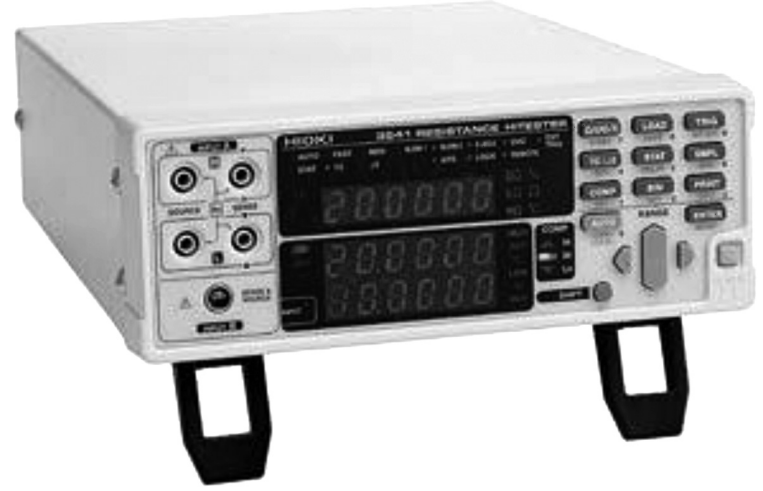

Figure 9: Temperature-dependent resistance-meter device Slika 9: Merilna naprava za merjenje specifične električne upornosti v odvisnosti od temperature

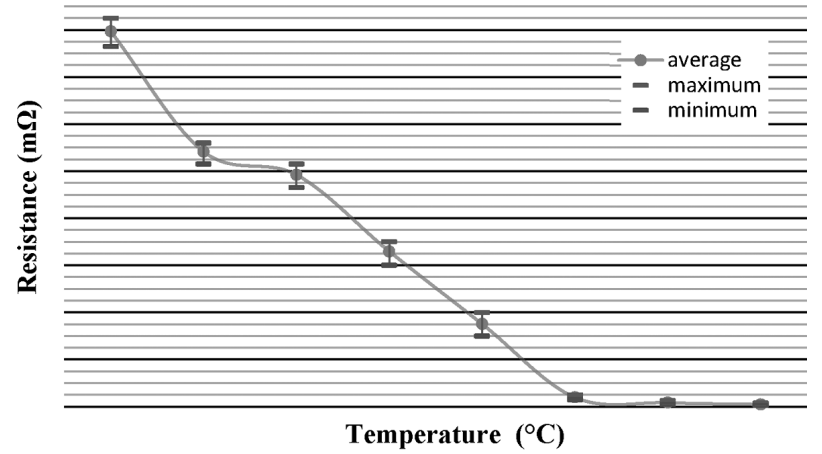

Figure 10: Resistance-temperature graph of ASC 100.29 powder-metal material with dimensions of $10 \mathrm{~mm} \times 10 \mathrm{~mm} \times 55 \mathrm{~mm}$

Slika 10: Upornost v odvisnosti od temperature sintranega izdelka iz prahu ASC 100,29 z dimenzijami $10 \mathrm{~mm} \times 10 \mathrm{~mm} \times 55 \mathrm{~mm}$

Table 3: Resistance-temperature average values for the ASC 100.29 powder-metal material with the dimensions of $10 \mathrm{~mm} \times 10 \mathrm{~mm} \times 55$ $\mathrm{mm}$

Tabela 3: Povprečne vrednosti upornosti na izbrani temperaturi za surovce $10 \mathrm{~mm} \times 10 \mathrm{~mm} \times 55 \mathrm{~mm}$ iz prahu ASC 100,29

\begin{tabular}{|c|c|}
\hline Temperature, $T /{ }^{\circ} \mathrm{C}$ & Resistance, $R / \mathrm{m} \Omega$ \\
\hline 20 & 159.4 \\
\hline 50 & 108.32 \\
\hline 100 & 98.507 \\
\hline 200 & 65.953 \\
\hline 300 & 35.14 \\
\hline 400 & 3.953 \\
\hline 500 & 1.72 \\
\hline 600 & 0.942 \\
\hline
\end{tabular}

the temperature. While sintering the PM materials with induction, different heat is generated in their inner structures based on their resistivity, compared to the bulk materials, and this affects the sintering with induction. The resistivity values calculated with these resistance values obtained from the PM samples were used in the numerical solutions of the sintering process with induction. The temperature-location graphs of the PM samples were obtained by means of numerical analyses in the

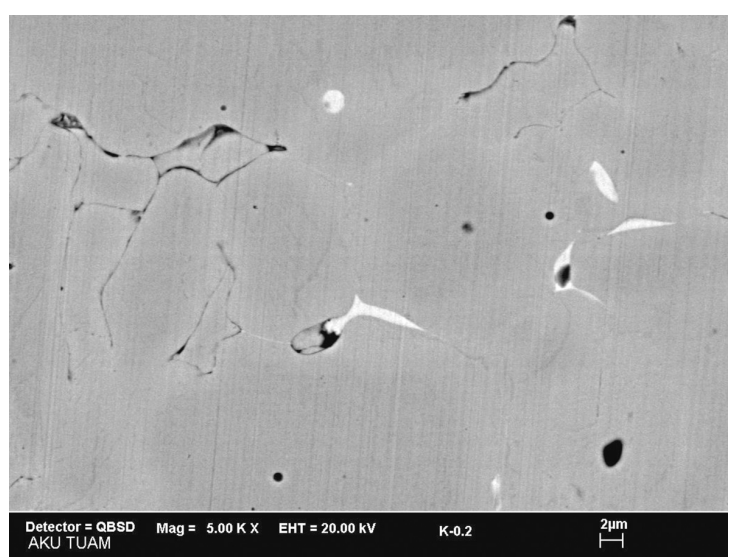

Figure 11: SEM image of K-0.2 sample, magnification of 5000-times Slika 11: SEM-posnetek mikrostrukture vzorca K-0.2, povečava 5000-kratna 
depths of the penetration in the preheating and sintering areas.

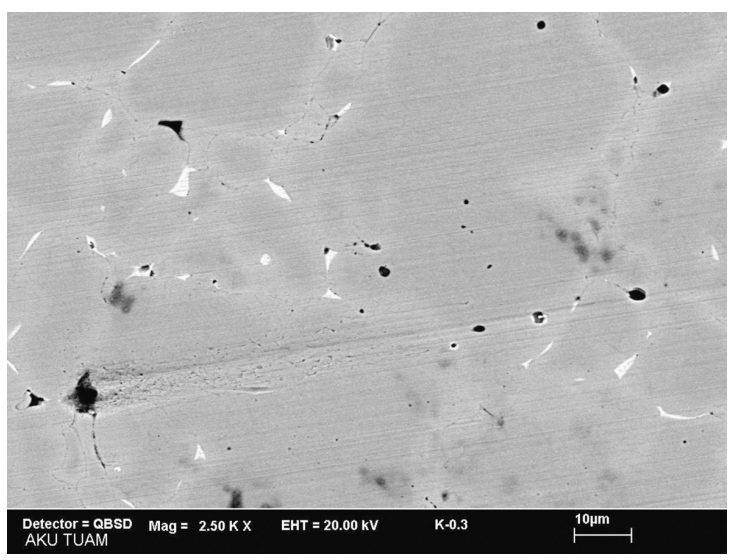

Figure 12: SEM image of K-0.3 sample, magnification of 2500-times Slika 12: SEM-posnetek mikrostrukture vzorca $\mathrm{K}-0.3$, povečava 2500-kratna

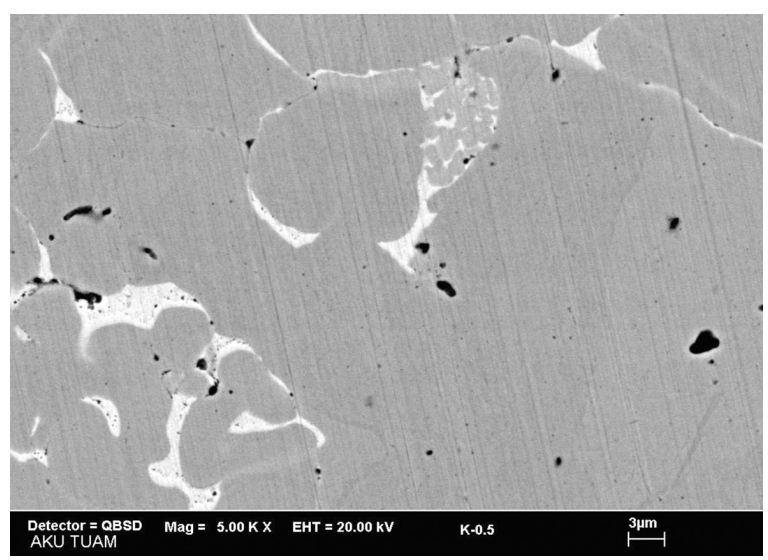

Figure 13: SEM image of K-0.5 sample, magnification of 5000-times Slika 13: SEM-posnetek mikrostrukture vzorca K-0.5, povečava 5000-kratna

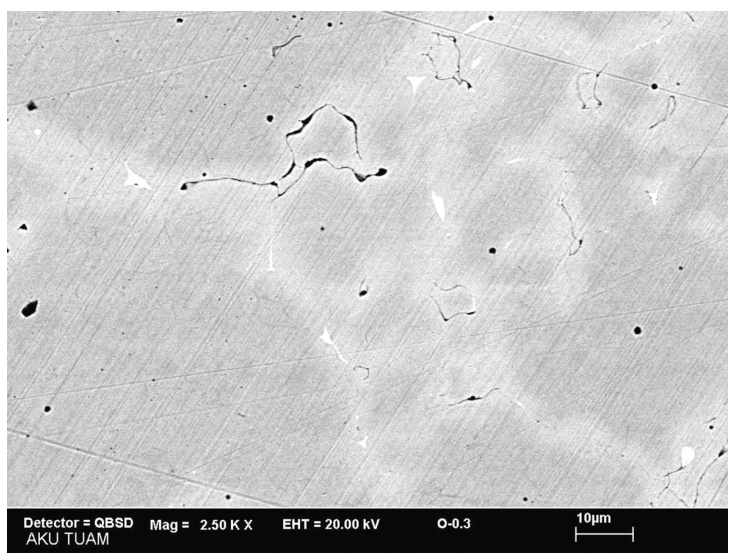

Figure 14: SEM image of Ö-0.3 sample, magnification of 2500-times Slika 14: SEM-posnetek mikrostrukture vzorca Ö-0.3, povečava 2500-kratna

\subsection{Metallographic analyses}

In order to examine the PM samples in the SEM BEC mode, they were cut in the dimensions of $1 \mathrm{~cm} \times 1 \mathrm{~cm} \times$ $1 \mathrm{~cm}$. The cut samples were sanded and polished with

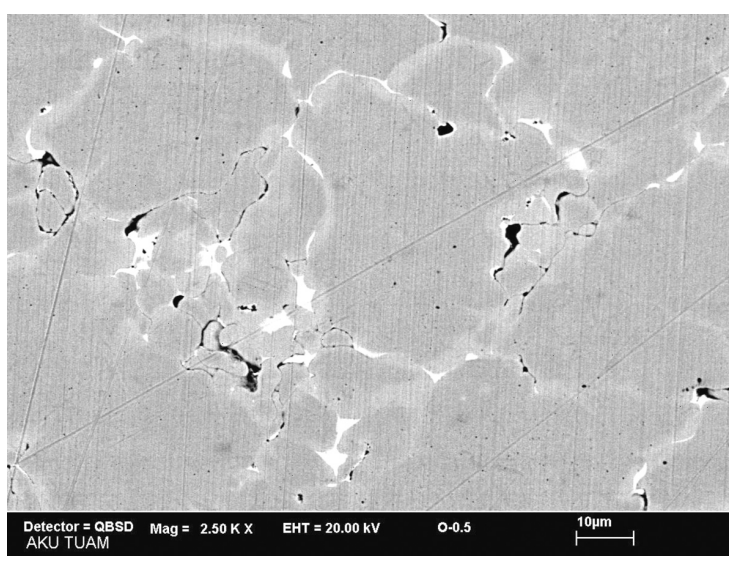

Figure 15: SEM image of Ö-0.5 sample, magnification of 2500-times Slika 15: SEM-posnetek mikrostrukture vzorca Ö-0.5, povečava 2500-kratna

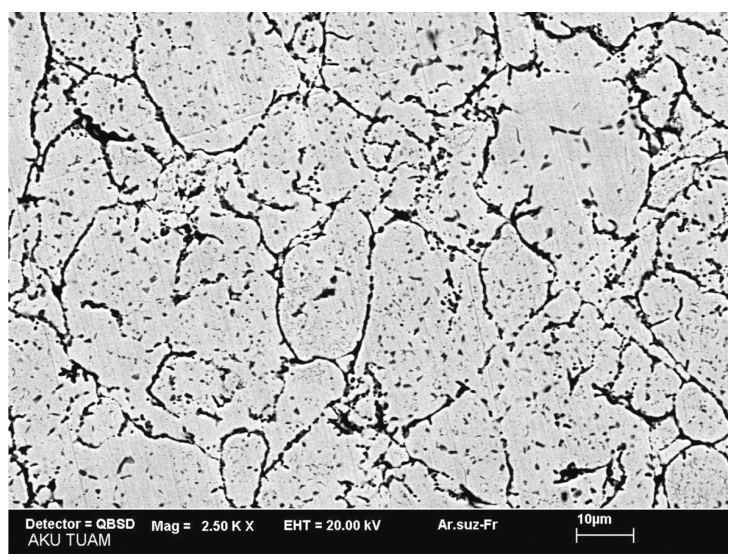

Figure 16: SEM image of F-2 sample, magnification of 2500-times Slika 16: SEM-posnetek mikrostrukture vzorca F-2, povečava 2500-kratna

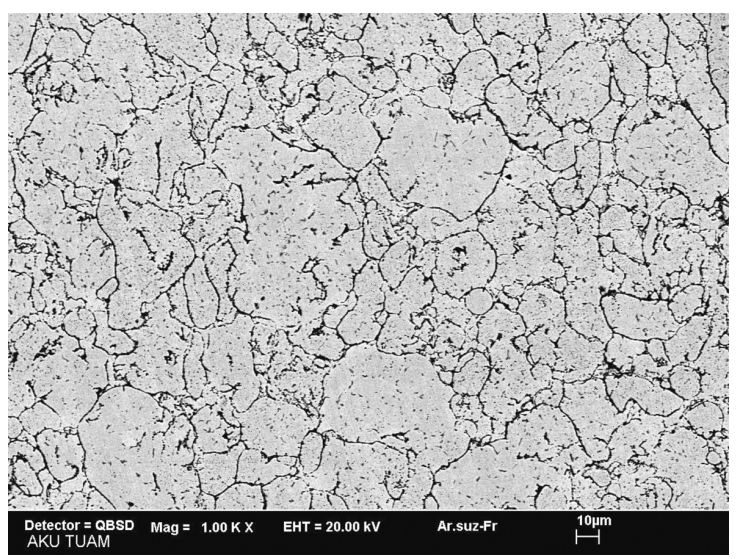

Figure 17: SEM image of F-2 sample, magnification of 1000-times Slika 17: SEM-posnetek mikrostrukture vzorca F-2, povečava 1000-kratna 


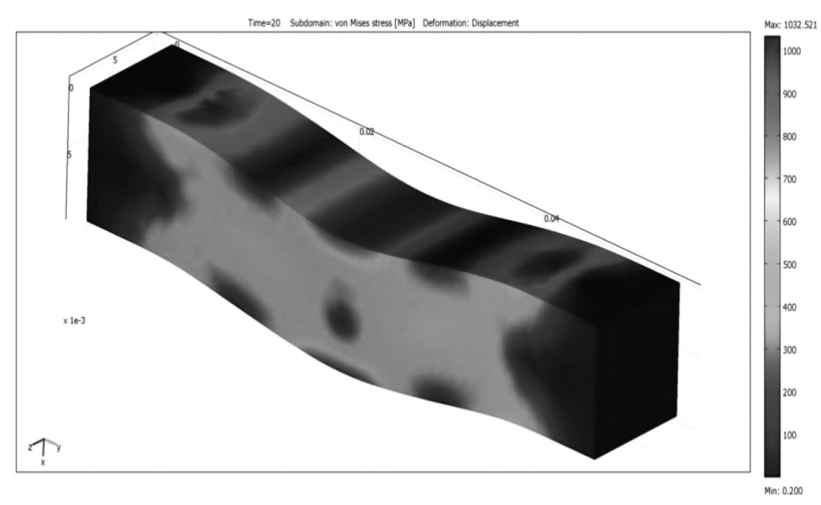

Figure 18: Three-point-bending strain numerical analysis Slika 18: Numerična analiza tritočkovnega upogibnega preizkusa the grits 240-400-600-800. The polished samples were analyzed with a scanning electron microscope (SEM). The SEM results of the PM samples are given in Figures 11 to 17.

\subsection{Theoretical studies}

In the theoretical studies, three-point-bending strength-strain (displacement) analyses of the PM samples were conducted. In addition, the penetration-depth calculations for the samples were conducted using the program numerically. In the numerical studies, the Comsol Multyphysics finite-element-analysis program was used. The obtained numerical data were compared with the experimental results.

\subsection{Mechanical analysis}

The three-point-bending test results for the samples were supported with the numerical three-point-bending analyses. The elasticity module and the Poisson rate connected with the density of the samples were obtained through the R-A approach. ${ }^{6}$ In Figure 18, an example of the three-point-bending numerical model established for each specimen is given (the bulk-sample Von Misses stress-strain model).

The three-point-bending and stain graphs for the samples modeled in the actual sizes and in the experi-

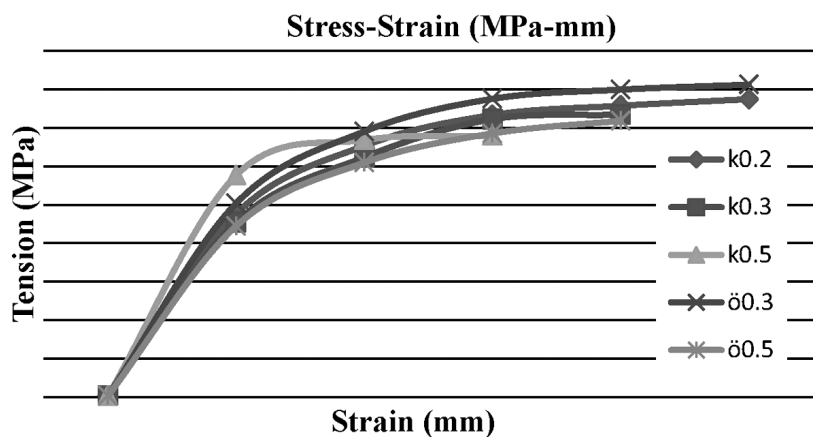

Figure 19: Numerical stress-strain curves of the samples sintered with induction

Slika 19: Numerično določene krivulje napetost - deformacija indukcijsko sintranih vzorcev

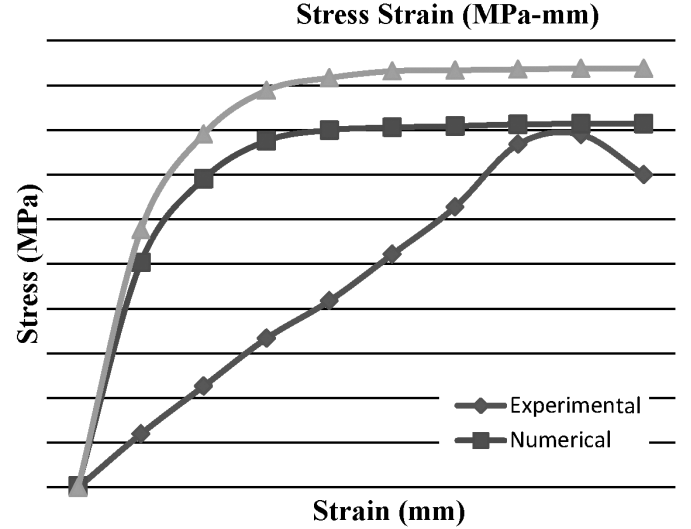

Figure 20: Experimental and numerical three-point-bending strainresistance results for the Ö0.3 sample

Slika 20: Eksperimentalno in numerično določeni rezultati tritočkovnega upogibnega preizkusa na vzorcu z oznako Ö0.3

mental boundary conditions are given in Figure 19. In the analyses, the elasticity module and the Poisson rate of the PM samples were obtained using the values from the R-A approach, accepting the isotropic-material features.

In Figure 20, the experimental and numerical threepoint-bending resistance results for the Ö0.3 samples are compared.

\subsection{Numerical analysis of the penetration depth}

The resistivity values calculated with the resistance values obtained from the experimental data were used in the numerical analyses and the penetration depths occurring in the preheating and sintering areas were calculated. In Figure 21, magnetic-flux lines are given for the preheating and sintering zones, and in Table 4, the parameters used in the program for the preheating and sintering zones are given. In the preheating process,

Table 4: Parameters used in the calculations

Tabela 4: Parametri, uporabljeni v izračunih

\begin{tabular}{|l|c|c|}
\hline \multicolumn{1}{|c|}{ Variables } & Preheating zone & Sintering zone \\
\hline Current & $10 \mathrm{~A}$ & $17.5 \mathrm{~A}$ \\
\hline Coil diameter & $0.004 \mathrm{~m}$ & $0.008 \mathrm{~m}$ \\
\hline Number of windings & 15 & 9 \\
\hline $\begin{array}{l}\text { Reference } \\
\text { temperature }\end{array}$ & $20^{\circ} \mathrm{C}$ & $20^{\circ} \mathrm{C}$ \\
\hline $\begin{array}{l}\text { Resistivity } \\
T=T_{0}=20^{\circ} \mathrm{C}\end{array}$ & $289 \times 10^{-6} \Omega \mathrm{m}$ & $289 \times 10^{-6} \Omega \mathrm{m}$ \\
\hline Density of argon & $1.784 \mathrm{~g} / \mathrm{cm}^{3}$ & $1.784 \mathrm{~g} / \mathrm{cm}^{3}$ \\
\hline Argon heat capacity & $0.52 \mathrm{~kJ} /(\mathrm{kg} \mathrm{K})$ & $0.52 \mathrm{~kJ} /(\mathrm{kg} \mathrm{K})$ \\
\hline $\begin{array}{l}\text { Thermal conductivity } \\
\text { of argon }\end{array}$ & $0.01772 \mathrm{~W} /(\mathrm{m} \mathrm{K})$ & $0.01772 \mathrm{~W} /(\mathrm{m} \mathrm{K})$ \\
\hline Density of crude iron & $6720 \mathrm{~kg} / \mathrm{m}^{3}$ & $6720 \mathrm{~kg} / \mathrm{m}^{3}$ \\
\hline Heat capacity of iron & $25.1 \mathrm{~J} /(\mathrm{mol} \mathrm{K})^{3}$ & $25.1 \mathrm{~J} /(\mathrm{mol} \mathrm{K})$ \\
\hline $\begin{array}{l}\text { Thermal conductivity } \\
\text { of iron }\end{array}$ & $58 \mathrm{~W} /(\mathrm{m} \mathrm{K})$ & $58 \mathrm{~W} /(\mathrm{m} \mathrm{K})$ \\
\hline Iron permeability & $8.75 \times 10^{-4} \mathrm{H} / \mathrm{m}$ & $8.75 \times 10^{-4} \mathrm{H} / \mathrm{m}$ \\
\hline Frequency & $2.5 \mathrm{kHz}$ & $45 \mathrm{kHz}$ \\
\hline
\end{tabular}




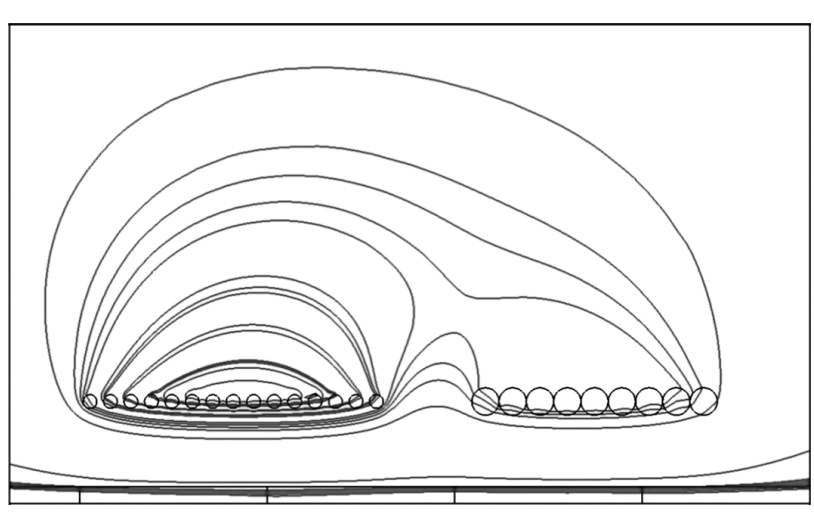

Figure 21: Magnetic-field lines in the preheating and sintering zones Slika 21: Magnetne silnice v conah predgrevanja in sintranja

a processing depth of $3.751 \mathrm{~mm}$ was obtained on the samples by means of a coil of a diameter $4 \mathrm{~mm}$. In the sintering zone, a penetration depth $2.56 \mathrm{~mm}$ was reached by means of a diameter coil $8 \mathrm{~mm}$.

\section{DISCUSSION}

Within the scope of the study, a continuous test rig was designed for the preheating and sintering with induction. The iron-based PM samples sintered with induction and in the furnace at $(0.2,0.3$ and 0.5$) \mathrm{mm} / \mathrm{s}$ conveyor speeds were investigated experimentally and theoretically.

The highest resistance and strain values were observed in the samples processed with the preheating at the $0.3 \mathrm{~mm} / \mathrm{s}$ conveyor speed and in the samples processed without preheating and at the conveyor speed of $0.2 \mathrm{~mm} / \mathrm{s}$ (Figures 6 and 7). The preheat application not only prevented the thermal shock on the samples but also allowed the lubricators to separate from the structure more stably. In the samples sintered with induction at the speeds slower than $0.5 \mathrm{~mm} / \mathrm{s}$, we obtained a higher level of resistance and a larger settling amount compared to the samples sintered in the furnace. In the atmospheric environment, it was observed that corrosion occurred on the samples sintered in the furnace and, thus, the threepoint-bending resistances decreased.

The lowest hardness value was detected in the sample sintered with induction at the $0.3 \mathrm{~mm} / \mathrm{s}$ preheating speed. This result was understood to arise from the hard oxide layer formed on the surfaces of the samples sintered in the furnace (Figure 8).

In the studies related to the resistances of the PM samples, the resistances of the samples sintered at room temperature and at high temperatures showed considerable differences. In the conducted experimental studies, the resistance-temperature graph for the Högensas ASC 100.29 iron-based powder was revealed. Contrary to the bulk metallic materials, an increase in the temperature of the PM samples decreased the resistivity. This reduction of a high proportion resulted in a decrease in the depth of penetration in the heating with induction for the PM materials. The resistivity values of the $10 \mathrm{~mm} \times 10 \mathrm{~mm}$ $\times 55 \mathrm{~mm}$ iron-based powder-metal particles are recorded in the literature. In the numerical analyses, the measured actual resistivity values for the PM samples were used.

The highest density value of $99.704 \%$ was measured for the sample sintered with induction at the conveyor speed of $0.3 \mathrm{~mm} / \mathrm{s}$ applied with the preheating. The internal structures of the samples sintered in the atmospheric environment of the furnace are quite different from those of the samples sintered with induction. In the samples sintered in the furnace, a heterogeneous distribution of the internal structure is observed, stemming from the harmful effects of the environment atmosphere (Figures 16 and 17). The induction current enabled the formation of a more uniform internal structure by ensuring a gradual and homogenous heating of the powder particles through a formation of a $3.751 \mathrm{~mm}$ processing depth, especially in the preheating zone of the 10 $\mathrm{mm} \times 10 \mathrm{~mm}$ sample section.

With the numerical three-point-bending results, the $\mathrm{RA}^{6}$ approach and the porosity-based elasticity modulus were obtained for each sample, and these values were used in the numerical analyses. Analyzing experimental and numerical three-point-bending resistance graphs for the PM samples, it was seen that the results overlap. However, these differences can be considered to stem from the orthotropic mechanical properties of the PM samples (Figure 20). As expected, not only in the experimental results but also in the numerical results, the resistance values of the samples were increased due to the increase in the duration of the sintering with induction. The highest three-point-bending resistance values were found for samples K0.2 and Ö0.3. Although the Ö0.3 sample was sintered faster than the K0.2 sample, the reason why it is denser is the extra preheating applied for $11.38 \mathrm{~min}$ at $600{ }^{\circ} \mathrm{C}$. For the Ö0.3 sample, the preheating process and the conveyor speed were observed to have positive effects on the mechanical properties and the microstructure. Although it is known that if the conveyor speed is further decreased, the density increases, it should be noted that this process also increases the costs. Therefore, it is concluded that in the induction sintering, rather than increasing the conveyor speed, preheating is better in terms of energy costs and an improvement in the mechanical and physical properties of the PM materials.

In the preheating zone, an area of about $2.49 \mathrm{~mm}$ within the sample was sintered with heat transfer. A positive effect of preheating on the internal structure and mechanical properties was supported with the experimental and numerical results. For the Ö0.3 sample processed with preheating, it was observed that the mechanical features similar to the ones of the K0.2 sample were achieved. Based on this result, it was observed that it could be possible to shorten the sintering duration by including preheating in the induction sintering of the PM parts and, therefore, decreasing the energy costs. 


\section{CONCLUSIONS}

The effects of the preheating process with induction at a medium/low frequency $(2.5 \mathrm{kHz})$ on the microstructural, mechanical and physical properties were investigated experimentally and numerically, and the following results were obtained:

- In the three-point-bending tests of the PM samples sintered with induction, an increase in the threepoint-bending resistance values was observed due to a conveyor-speed reduction (an increase in the sintering time) (Figures 6 and 7).

- Considering the Brinell surface-hardness test results, a higher surface hardness was observed for the samples sintered in the furnace compared to the samples sintered with induction. The lowest hardness value was detected for the sample sintered with induction at a $0.3 \mathrm{~mm} / \mathrm{s}$ preheating speed.

- In the metallographic studies, the microstructure (SEM) images of the samples were found to be quite different. In the case of the K0.2 sample where the conveyor speed was the lowest, it was observed that copper filled in the microcavities through the phase sintering (Figure 11). Furthermore, it was observed that the pores decreased with the conveyor-speed reduction (an increase in the sintering time) and the density increased.

- Using the resistivity values obtained for the PM samples in the numerical analysis, the penetration depths in the preheating and sintering zones were calculated. In the numerical analyses conducted on the basis of the axis of symmetry, a processing depth of $3.751 \mathrm{~mm}$ in the preheating zone and a depth of $2.56 \mathrm{~mm}$ in the sintering zone were obtained.

\section{REFERENCES}

${ }^{1}$ A. Lawley, Atomization: The production of metal powders, Metal Powder Industries Federation, Princeton, New Jersey, USA 1992

${ }^{2}$ R. M. German, Powder metallurgy and particulate materials processing, translation: Sarıtaş-Türker-Durlu, Turkish Powder Metallurgy Association, Ankara 2007, 150-151

${ }^{3}$ B. H. Yüksel, The Use of Third Harmonic High Frequency Induction Furnace Design, Master's Thesis, Electrical Education, Gazi University Institute of Science, Ankara, Turkey, 2006

${ }^{4}$ Ç. Sevilay, One Phase Induction Heating System Analysis and Design, Master's Thesis, Pamukkale University, Institute of Science and Technology, Denizli/Turkey, 2005

${ }^{5}$ www.hoganas.com, Available from the World Wide Web: 13.06.2013

${ }^{6}$ N. Ramakrishnan, V. S. Arunachalam, Effective Elastic Moduli of Ceramic Materials, Journal of the American Ceramic Society, 76 (1993), 2745-2752, doi:10.1111/j.1151-2916.1993.tb04011.x 